\title{
Pharmacokinetics of Orally Administered Tacrolimus in Lupus Nephritis Patients
}

\author{
Keiko UChida, ${ }^{*}$ Yukari AsamiYa, Takashi TAKeI, Mitsuyo ItABashi, \\ Hidekazu SugiURA, Misao TsuKadA, and Kosaku NitTA \\ Department of Medicine, Kidney Center, Tokyo Women's Medical University, \\ 8-1 Kawada-cho, Shinjuku-ku, Tokyo 162-8666, Japan
}

(Received May 3, 2009; Accepted September 23, 2009; Published online October 7, 2009)

\begin{abstract}
The pharmacokinetics of orally administered tacrolimus were examined in six female lupus nephritis patients (mean age 43 years, range $24-55$ years). Tacrolimus ( $3 \mathrm{mg}$ ) was administered after supper, and blood tacrolimus concentrations were measured just prior to dosing and 1, 2, 4, 6, 8, 12 and $24 \mathrm{~h}$ after administration. The maximum blood concentration $\left(\mathrm{C}_{\max }\right)$ was observed $4-8 \mathrm{~h}$ (mean: $6.7 \mathrm{~h}$ ) after administration. The mean $\mathrm{C}_{\max }$ and area under the tacrolimus concentrationti-me curve $\left(\mathrm{AUC}_{0-24 \mathrm{~h}}\right)$ were $12.7 \mathrm{ng} / \mathrm{ml}$ and $163.1 \mathrm{ng} \cdot \mathrm{h} / \mathrm{ml}$, respectively. Although there was a weak correlation between $\mathrm{AUC}_{0-24 \mathrm{~h}}$ values and tacrolimus concentrations 2, 4, and $6 \mathrm{~h}$ after administration, concentrations at 12 $\mathrm{h}$ and $24 \mathrm{~h}$ were highly correlated with $\mathrm{AUC}_{0-24 \mathrm{~h}}$ values, suggesting that the trough concentration $\left(\mathrm{C}_{24 \mathrm{~h}}\right)$ and $\mathrm{C}_{12 \mathrm{~h}}$ are valid markers for therapeutic tacrolimus monitoring. Enzyme-linked immunoabsorbent assay (ELISA) and microparticle enzyme immunoassay (MEIA) measurements of blood tacrolimus concentrations were similar. We recommend that monitoring should be carried out by $\mathrm{C}_{12 \mathrm{~h}}$ in lupus nephritis outpatients.
\end{abstract}

Key words — tacrolimus; lupus nephritis; pharmacokinetics; enzyme-linked immunoabsorbent assay (ELISA); microparticle enzyme immunoassay (MEIA)

\section{INTRODUCTION}

Tacrolimus, a T-cell specific calcineurin inhibitor, is widely used for transplant patients. The efficacy and safety profiles of tacrolimus as an immunosuppressive agent that prevents graft rejection are well defined. ${ }^{1)}$ In Japan, tacrolimus was approved for use in lupus nephritis patients in January 2007 and is expected to be efficacious in patients whose steroid treatment have to be discontinued..$^{2-4)}$

Because tacrolimus shows considerable interindividual pharmacokinetic variability, therapeutic drug monitoring of trough blood concentrations is necessary to avoid rejection and adverse effects in transplant patients. Over the years, a large number of pharmacokinetic studies have been carried out in healthy subjects and solid organ transplant patients, who usually receive tacrolimus twice-a-day. ${ }^{5-8)}$ However, there have been few studies of the pharmacokinetics of tacrolimus in lupus nephritis patients or other patients who receive tacrolimus once daily. The pharmacokinetic profile of tacrolimus differs in fed and fasted conditions; the blood concentrations of tacrolimus decrease after meals. ${ }^{9}{ }^{910}$ In addition, some investigators have reported that the pharmacokinetic

\footnotetext{
*e-mail: kuchida@kc.twmu.ac.jp
}

profile differs between morning and evening doses. ${ }^{11-13)}$

In this paper, pharmacokinetic profiles were investigated in lupus nephritis patients after evening administration of tacrolimus. The appropriate time to monitor the blood tacrolimus concentrations in these patients is discussed.

\section{MATERIALS AND METHODS}

Six female lupus nephritis patients (mean age 43 years, range 24-55 years) who were admitted to the Kidney Center in Tokyo Women's Medical University (Tokyo) between October 2007 and May 2008 were the subjects of this study. A $3 \mathrm{mg}$ tacrolimus capsule (Prograf $^{\circledR}$, Astellas Pharma Inc., Tokyo, Japan) was administered once a day to these patients after supper. All study has performed more than fourteen days after patient started to administer of tacrolimus. The drugs that are known to affect the tacrolimus blood concentrations were not co-administered. Blood was collected just before administration and 1, 2, 4, 6, 8, 12 and $24 \mathrm{~h}$ after administration. The blood concentration of tacrolimus was measured by enzyme-linked immunoabsorbent assay (ELISA), ${ }^{14)}$ as well as by microparticle enzyme immunoassay (MEIA) ${ }^{15)}$ in two subjects.

The maximum blood concentration $\left(\mathrm{C}_{\max }\right)$ and 
time to reach the maximum concentration $\left(\mathrm{T}_{\max }\right)$ were obtained directly from the data. The area under the tacrolimus concentration-time curve between 0 and $24 \mathrm{~h}\left(\mathrm{AUC}_{0-24 \mathrm{~h}}\right)$, the last measurement point, was determined by the linear trapezoidal rule.

The study protocol was reviewed and approved by the Institutional Review Board at Tokyo Women's Medical University, and written informed consent was obtained from each patient before initiation of any study-related procedures.

\section{RESULTS}

All of the patients enrolled in this study were female. Mean age, body weight, and time with systemic lupus erythematosus (SLE) were $43.0 \mathrm{y}, 49.8 \mathrm{~kg}$, and $15.1 \mathrm{y}$, respectively (Table 1 ). Urinary protein, serum $\mathrm{C} 3$ level, serum complement hemolytic activity $(\mathrm{CH} 50)$, and serum anti-dsDNA antibody titer were stable in these patients, and tacrolimus was administered for the purpose of corticosteroid sparing.

Blood tacrolimus concentrations after oral administration of $3 \mathrm{mg}$ tacrolimus are shown in Fig. 1, and pharmacokinetic parameters are summarized in Table 2. The mean $\mathrm{T}_{\max }$ was $6.7 \mathrm{~h}$ (range: $4-8 \mathrm{~h}$ ).
Mean $\mathrm{C}_{\max }$ and $\mathrm{AUC}_{0-24 \mathrm{~h}}$ were $12.7 \mathrm{ng} / \mathrm{ml}$ and 163.1 $\mathrm{ng} \cdot \mathrm{h} / \mathrm{ml}$, respectively, and dose-normalized $\mathrm{C}_{\max }$ $\left(\mathrm{C}_{\max } /\right.$ Dose $), \mathrm{C}_{24 \mathrm{~h}} \quad\left(\mathrm{C}_{24 \mathrm{~h}} /\right.$ Dose $)$, and $\mathrm{AUC}_{0-24 \mathrm{~h}}$ $\left(\mathrm{AUC}_{0-24 \mathrm{~h}} /\right.$ Dose $)$ values were $207(\mathrm{ng} / \mathrm{ml}) /(\mathrm{mg} /$ $\mathrm{kg}), 67(\mathrm{ng} / \mathrm{ml}) /(\mathrm{mg} / \mathrm{kg})$, and $2641(\mathrm{ng} \cdot \mathrm{h} / \mathrm{ml}) /$

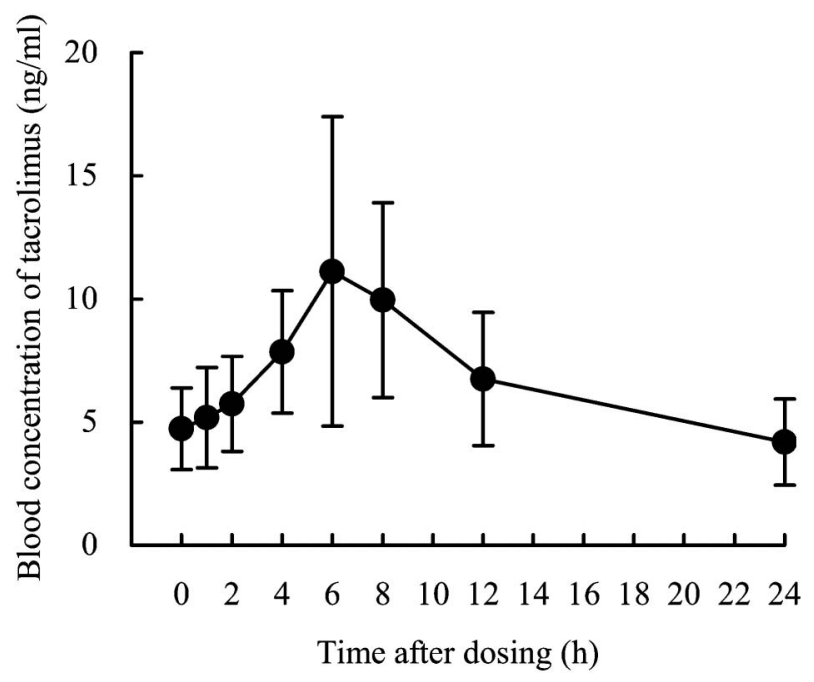

Fig. 1. Blood Concentration of Tacrolimus after Oral Administration to Lupus Nephritis Patients Results represent the means \pm S.D. of six patients.

Table 1. Characteristics of Lupus Nephritis Patients

\begin{tabular}{ccccccccc}
\hline \hline Patient & Gender & $\begin{array}{c}\text { Age } \\
(\mathrm{y})\end{array}$ & $\begin{array}{c}\text { Body weight } \\
(\mathrm{kg})\end{array}$ & $\begin{array}{c}\text { Duration of } \\
\text { disease }(\mathrm{y})\end{array}$ & $\begin{array}{c}\text { Proteinurea } \\
(\mathrm{g} / \mathrm{day})\end{array}$ & $\begin{array}{c}\mathrm{C} 3 \\
(\mathrm{mg} / \mathrm{dl})\end{array}$ & $\begin{array}{c}\text { CH50 } \\
(\mathrm{U} / \mathrm{ml})\end{array}$ & $\begin{array}{c}\text { Anti-dsDNA } \\
\text { antibody }(\mathrm{IU} / \mathrm{ml})\end{array}$ \\
\hline 1 & $\mathrm{~F}$ & 44 & 42.2 & 25 & 0.50 & 107.1 & 52.0 & 0.3 \\
2 & $\mathrm{~F}$ & 41 & 50.5 & 6 & 0.20 & 46.4 & 23.5 & $>35$ \\
3 & $\mathrm{~F}$ & 55 & 43.9 & 0.5 & 0.44 & 79.7 & 43.0 & 0.4 \\
4 & $\mathrm{~F}$ & 44 & 62.9 & 17 & 2.63 & 58.8 & 23.9 & 2.0 \\
5 & $\mathrm{~F}$ & 24 & 46.3 & 13 & 0.37 & 118.5 & 38.4 & 0.4 \\
6 & $\mathrm{~F}$ & 50 & 53.0 & 29 & 1.80 & 39.5 & 18.6 & 9.8 \\
\hline Mean & - & 43.0 & 49.8 & 15.1 & 0.99 & 75.0 & 33.2 & -13.2 \\
S.D. & - & 10.6 & 7.6 & 10.9 & 0.99 & 32.5 & 13.2 \\
\hline
\end{tabular}

Table 2. Pharmacokinetic Parameters of Tacrolimus after Oral Administration to Lupus Nephritis Patients

\begin{tabular}{ccccccccc}
\hline \hline Patient & $\begin{array}{c}\mathrm{T}_{\max } \\
(\mathrm{h})\end{array}$ & $\begin{array}{c}\mathrm{C}_{\max } \\
(\mathrm{ng} / \mathrm{ml})\end{array}$ & $\begin{array}{c}\mathrm{C}_{\max } / \text { Dose } \\
([\mathrm{ng} / \mathrm{ml}] /[\mathrm{mg} / \mathrm{kg}])\end{array}$ & $\begin{array}{c}\mathrm{AUC}_{0-24 \mathrm{~h}} \\
(\mathrm{ng} \cdot \mathrm{h} / \mathrm{ml})\end{array}$ & $\begin{array}{c}\mathrm{AUC}_{0-24 \mathrm{~h}} / \mathrm{Dose} \\
([\mathrm{ng} \cdot \mathrm{h} / \mathrm{ml}] /[\mathrm{mg} / \mathrm{kg}])\end{array}$ & $\begin{array}{c}\mathrm{C}_{12 \mathrm{~h}} \\
(\mathrm{ng} / \mathrm{ml})\end{array}$ & $\begin{array}{c}\mathrm{C}_{24 \mathrm{~h}} \\
(\mathrm{ng} / \mathrm{ml})\end{array}$ & $\begin{array}{c}\mathrm{C}_{24 \mathrm{~h}} / \mathrm{Dose} \\
([\mathrm{ng} / \mathrm{ml}] /[\mathrm{mg} / \mathrm{kg}])\end{array}$ \\
\hline 1 & 8 & 12 & 169 & 212.6 & 2991 & 10 & 6.3 & 89 \\
2 & 6 & 13 & 219 & 129.1 & 2173 & 4.4 & 2.8 & 47 \\
3 & 8 & 9.9 & 145 & 142.2 & 2081 & 6.4 & 3.6 & 53 \\
4 & 8 & 9.0 & 189 & 135.3 & 2837 & 6.0 & 3.3 & 69 \\
5 & 6 & 23 & 355 & 258.2 & 3985 & 10 & 6.5 & 46 \\
6 & 4 & 9.4 & 166 & 100.9 & 1783 & 3.7 & 2.6 & 46 \\
\hline Mean & 6.7 & 12.7 & 207 & 163.1 & 2641 & 6.8 & 4.2 & 67 \\
S.D. & 1.6 & 5.3 & 77 & 59.5 & 804 & 2.7 & 1.8 & 23 \\
\hline
\end{tabular}


$(\mathrm{mg} / \mathrm{kg})$, respectively. There was not an obvious correlation between body weight and $\mathrm{C}_{\max }, \mathrm{C}_{24} \mathrm{~h}$, or $\mathrm{AUC}_{0-24 \mathrm{~h}}$ (Fig. 2).

The relationship between $\mathrm{AUC}_{0-24 \mathrm{~h}}$ and blood tacrolimus concentration at each time point is shown in Fig. 3. The best correlation was observed $24 \mathrm{~h}$ after administration $\left(\mathrm{C}_{24 \mathrm{~h}}\right) \quad\left(\mathrm{r}^{2}: 0.9437\right)$, followed by $\mathrm{C}_{12 \mathrm{~h}}$ and $\mathrm{C}_{8 \mathrm{~h}}$, whereas the $\mathrm{r}^{2}$ values for $\mathrm{C}_{2 \mathrm{~h}}, \mathrm{C}_{4 \mathrm{~h}}$, and $\mathrm{C}_{6 \mathrm{~h}}$ were between 0.3583 and 0.6249 .

Blood tacrolimus concentrations in patients 5 and 6 were measured by MEIA, as well as ELISA. The estimated concentrations by MEIA were similar to ELISA determinations; an excellent correlation was found between these measurements $\left(r^{2}: 0.9644\right.$, Fig. 4).

No patient experienced disease flare during tacrolimus therapy and serious adverse effect. During tacrolimus therapy for one year, the mean rate of steroid reduction was about $20 \%$.

\section{DISCUSSION}

In healthy volunteers, the $T_{\max }$ for tacrolimus is $1.34 \mathrm{~h}$ when it is orally administered before a meal and 3.22-3.41 $\mathrm{h}$ when it is orally administered after a meal. ${ }^{10)}$ When tacrolimus is orally administered $1 \mathrm{~h}$ after breakfast or $3 \mathrm{~h}$ after supper to renal transplant patients, $T_{\max }$ values are approximately $3 \mathrm{~h}$ and $4 \mathrm{~h}$, respectively. ${ }^{11)}$ Oral administration of tacrolimus to kidney transplant patients $30 \mathrm{~min}$ after breakfast or supper yields $T_{\max }$ values of $3.1 \mathrm{~h}$ and $7.5 \mathrm{~h}$, respectively. ${ }^{16)}$ Thus, the $T_{\max }$ seems to be delayed by supper intake. Furthermore, in liver transplant patients, the $\mathrm{T}_{\max }$ is prolonged in the evening $(2.9-3.5 \mathrm{~h})$ compared to the morning $(1.6 \mathrm{~h}) .^{12,13)}$ In this study, the mean $\mathrm{T}_{\max }$ after oral administration of tacrolimus to lupus nephritis patients was $6.7 \mathrm{~h}$ (range: $4-8 \mathrm{~h}$, Table 2). The prolonged $T_{\max }$ observed in lupus nephritis patients as well as in transplant patients is speculated to be due to supper intake and/or nighttime pharmacokinetics.

Although blood tacrolimus concentrations including $\mathrm{C}_{\max }$ and AUC varied by approximately 2 -fold between individuals, there was not a marked correlation between blood tacrolimus concentrations and body weight. Tacrolimus is eliminated mainly through metabolism in the liver and intestine, and the pharmacokinetics of tacrolimus may be affected by a number of factors, including liver function, kidney function, and interindividual variations in drug-
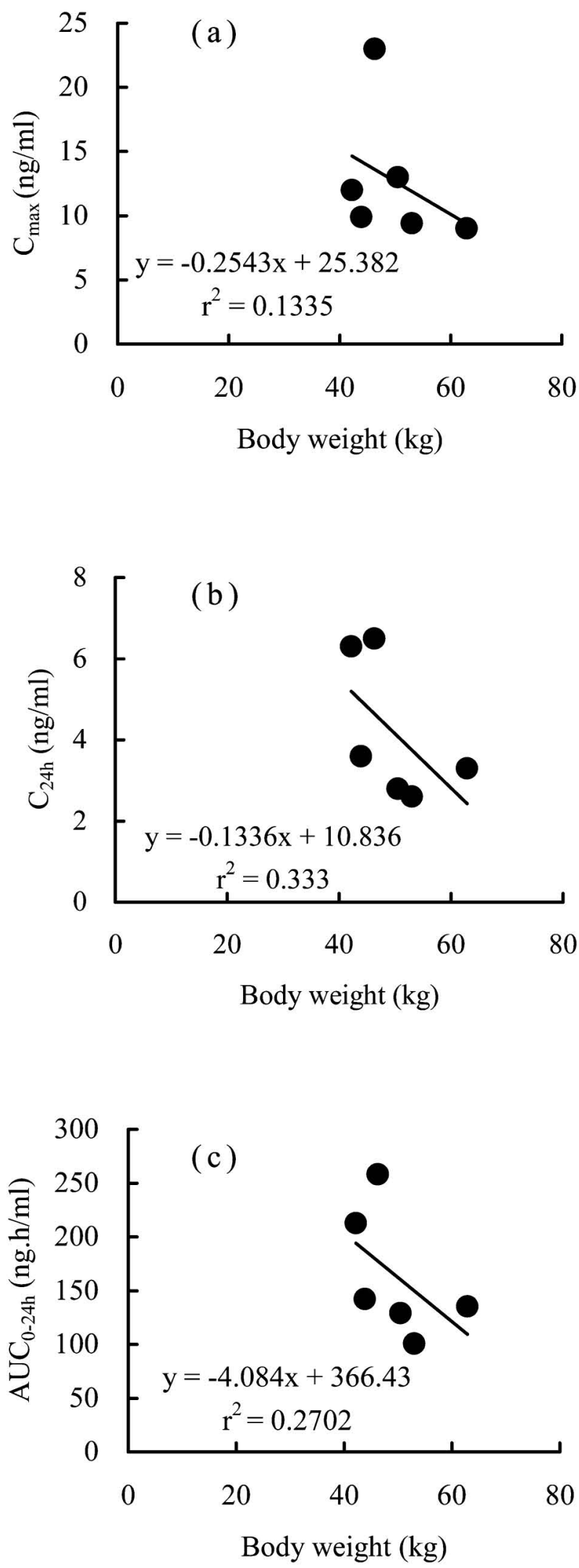

Fig. 2. Relationship between Blood Tacrolimus Concentration and Body Weight of Lupus Nephritis Patients

$\mathrm{C}_{\max }$ (a), $\mathrm{C}_{24 \mathrm{~h}}$ (b), and $\mathrm{AUC}_{0-24 \mathrm{~h}}$ (c) were plotted against body weights of patients. 

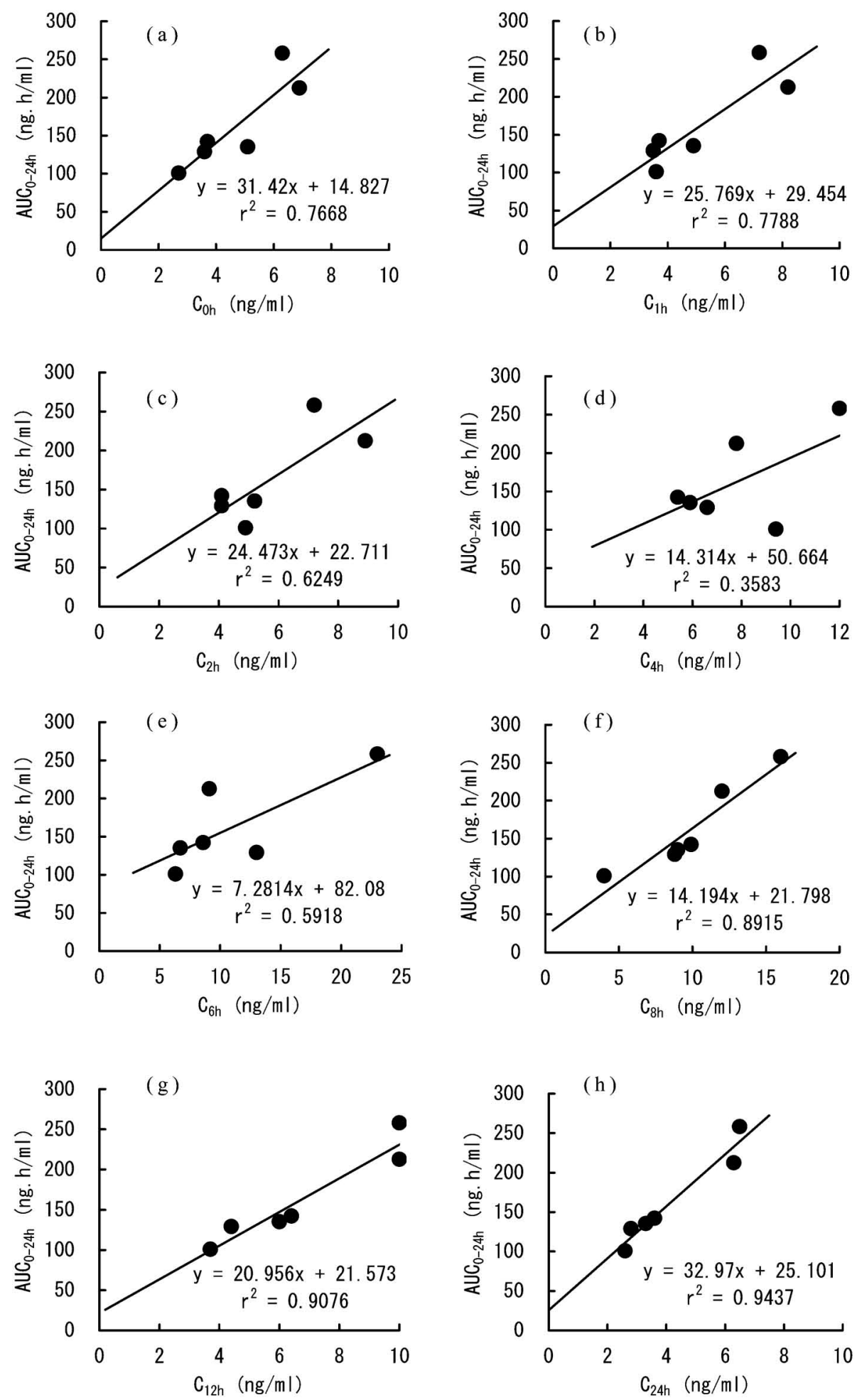

Fig. 3. Relationship between Blood Concentration and AUC after Oral Administration of Tacrolimus to Lupus Nephritis Patients $\mathrm{AUC}_{0-24 \mathrm{~h}}$ values were plotted against blood concentrations at $0 \mathrm{~h}(\mathrm{a}), 1 \mathrm{~h} \mathrm{(b)}, 2 \mathrm{~h} \mathrm{(c),} 4 \mathrm{~h}(\mathrm{~d}), 6 \mathrm{~h}(\mathrm{e}), 8 \mathrm{~h}(\mathrm{f}), 12 \mathrm{~h}(\mathrm{~g})$, and $24 \mathrm{~h}(\mathrm{~h})$ after administration.

metabolizing enzymes, such as CYP3A4/5 and multidrug resistance protein 1 (MDR1) ${ }^{6,7,17,18)}$ Thus, it seems that the tacrolimus pharmacokinetics may be affected by interindividual variations in the factors mentioned above rather than the treatment for lupus nephritis. Although it is well known that most of the adverse effects occurred at a trough concentration higher than $20 \mathrm{ng} / \mathrm{ml},{ }^{18)}$ all of the $\mathrm{C}_{12 \mathrm{~h}}$ values in this 


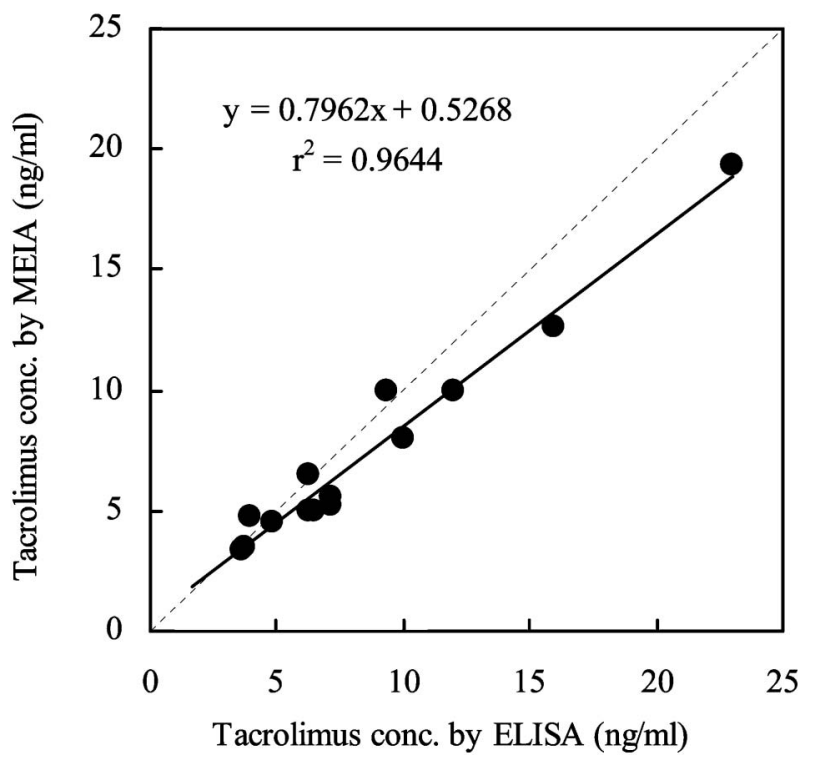

Fig. 4. Comparison of ELISA and MEIA Measurements of Tacrolimus Concentrations in Blood Samples from Lupus Nephritis Patients

study were less than $20 \mathrm{ng} / \mathrm{ml}$. The therapeutic range of blood concentration relating to the efficacy of tacrolimus in lupus nephritis is still unknown. ${ }^{19)}$ As the limitations of this study were the small number of patients, verification of these observations will require further studies with an increased patient sample size.

Because AUC is generally thought to be correlated with trough concentration $\left(\mathrm{C}_{12 \mathrm{~h}}\right)$ in transplant patients who are treated with tacrolimus twice a day, blood tacrolimus concentrations are monitored by $\mathrm{C}_{12 \mathrm{~h}}{ }^{6,20)}$ In this study, AUC was best correlated with $\mathrm{C}_{24 \mathrm{~h}}$, followed by $\mathrm{C}_{12 \mathrm{~h}}$, whereas $\mathrm{C}_{2 \mathrm{~h}}, \mathrm{C}_{4 \mathrm{~h}}$ and $\mathrm{C}_{6 \mathrm{~h}}$ were less significantly correlated (Fig. 3). An explanation for these phenomena may be due to the interindividual variations in $T_{\max }$. Tacrolimus is administered once a day to patients with lupus nephritis. Therefore, it seems that monitoring should be carried out using $\mathrm{C}_{12 \mathrm{~h}}$ or $\mathrm{C}_{24 \mathrm{~h}}$ levels in lupus nephritis patients. $\mathrm{C}_{12 \mathrm{~h}}$ monitoring is particularly convenient, because $\mathrm{C}_{12 \mathrm{~h}}$ for an evening outpatient dose can be measured when the patient visits the hospital the next morning. Thus, tacrolimus monitoring differs from that of cyclosporine, which is monitored by AUC or $\mathrm{C}_{2 \mathrm{~h}}$ levels, because $\mathrm{C}_{2 \mathrm{~h}}$ is correlated most closely with AUC for cyclosporine. ${ }^{20)}$

Blood concentrations of tacrolimus measured by MEIA were thought to be similar to those measured by ELISA until recently when it was reported that MEIA yields significantly higher blood tacrolimus concentrations than ELISA, especially in blood samples with a low hematocrit. ${ }^{21,22)} \mathrm{We}$ analyzed samples from two lupus nephritis patients by MEIA and found that the estimated tacrolimus concentrations by MEIA were similar to ELISA estimates (Fig. 4).

In conclusion, when tacrolimus is orally administered to lupus nephritis patients after supper, the $\mathrm{T}_{\max }$ is $4-8 \mathrm{~h}$. Thus, we recommend that monitoring should be carried out by $\mathrm{C}_{12 \mathrm{~h}}$ in lupus nephritis patients. In addition, tacrolimus concentrations estimated by MEIA were nearly identical to those estimated by ELISA.

\section{REFERENCES}

1) Goto T., Kino T., Hatanaka H., Okuhara M., Kohsaka M., Aoki H., Imanaka H., Transplant. Proc., 23, 2713-2717 (1991).

2) Politt D., Heintz B., Floege J., Mertens P. R., Clin. Nephrol., 62, 49-53 (2004).

3) Uchida K., Nitta K., Sogo Rinsho, 56, 20872092 (2007).

4) Asamiya Y., Uchida K., Suzuki K., Sugiura H., Itabashi M., Tsukada M., Yoda S., Takei S., Nitta K., Jpn. J. Nephrol., 50, 294 (2008).

5) Bekersky I., Dressler D., Colburn W., Mekki Q. A., J. Clin. Pharmacol., 39, 1032-1037 (1999).

6) Kawamura A., Jpn. J. Therap. Drug Monit., 20, 233-240 (2003).

7) Niwa T., Shiraga T., Omura M., Kondo T., Kuroda M., Takagi A., Folia Pharmacol. Jpn., 128, 395-404 (2006).

8) Boswell G. W., Bekersky I., Fay J., Wingard J., Antin J., Weidorf D., Maher R., Fizsimmons W., Nash R., Bone Marrow Transplant., 21, 23-28 (1998).

9) Bekersky I., Dressler D., Mekki Q. A., J. Clin. Pharmacol., 41, 176-182 (2001).

10) Bekersky I., Dressler D., Mekki Q. A., J. Clin. Pharmacol., 41, 289-297 (2001).

11) Tada H., Satoh S., Iinuma M., Shimoda N., Murakami M., Hayase Y., Kato T., Suzuki T., J. Clin. Pharmacol., 43, 859-865 (2003).

12) Min D. I., Chen H.-Y., Fabrega A., Ukah F. O., Wu Y.-M., Corwin C., Ashton M. K., Martin M., Transplantation, 62, 1190-1192 (1996) . 
13) Min D. I., Chen H.-Y., Lee M.-K., Ashton K. R. N., Martin M., Pharmacotherapy, 17, 457463 (1997).

14) Tamura K., Kobayashi M., Hashimoto K., Kojima K., Nagase K., Iwasaki K., Kaizu T., Tanaka H., Niwa M., Transplant. Proc., 19, 23-29 (1987).

15) Taylor P. J., Morris R. G., Ther. Drug Monit., 25, 259-260 (2003).

16) Iwahori T., Takeuchi H., Matsuo N., Johjima Y., Konno O., Nakamura Y., Hama K., Uchiyama M., Ashizawa T., Okuyama K., Nagao T., Abudoshukur M., Hirano T., Oka K., Transplant. Proc., 37, 1739-1740 (2005).

17) Staatz C. E., Tett S. E., Clin. Pharmacokinet., 43, 623-653 (2004).

18) Masuda M., Inui K. Pharmacol. Ther., 112,
184-198 (2006).

19) Tanaka H., Oki E., Tsugawa K., Nonaka K., Suzuki K., Ito E., Lupus, 16, 896-900 (2007).

20) Takeichi H., Matsuno N., Senuma K., Hirano T., Yokoyama T., Taira S., Kihara Y., Kuzuoka K., Konno O., Jojima Y., Mejit A., Akashi I., Nakamura Y., Iwamoto H., Hama K., Iwahori T., Ashizawa T., Nagao T., Roraishi T., Okuyama K., Oka K., Unezaki S., Biol. Pharm. Bull., 31, 90-94 (2008).

21) Hermida J., Fernandez C., Tutor J. C., Clin. Lab., 51, 43-45 (2005).

22) Katsuyama Y., Mizutani M., Matsunaga T., Omori S., Harada M., Kai H., Kumagaya H., Kosaka M., Iyaku to Yakugaku, 57, 743-749 (2007). 